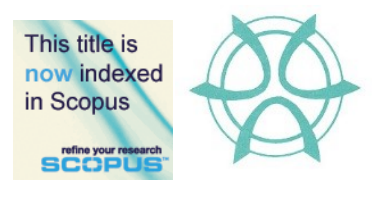

\title{
SPATIAL ANALYSIS OF CRIME HOT-SPOT IN THE NORTHEAST PENANG ISLAND DISTRICT AND KUCHING DISTRICT, MALAYSIA
}

\author{
Tarmiji Masron $^{1}$, Azizan Marzuki ${ }^{2}$, Nur Faziera Yaakub ${ }^{3}$, Mohd Norashad \\ Nordin $^{4}$, Norita Jubit ${ }^{5}$ \\ ${ }^{1,3,4,5}$ Centre for Spatially Integrated Digital Humanities (CSIDH) \\ Faculty of Social Sciences and Humanities (FSSH) \\ UNIVERSITI MALAYSIA SARAWAK (UNIMAS) \\ ${ }^{2}$ School of Housing, Building and Planning \\ UNIVERSITY SAINS MALAYSIA
}

\begin{abstract}
Over time, the relation between criminal acts with drug abuse cases has been discussed pedantically. From social and spatial points of view, this paper aims to determine the hot spot areas of burglary cases in the Northeast Penang Island District and Kuching District. The gained results of burglary cases are then being correlated with the presence of drug abuse cases. Both study areas came with location coordinates of the incident based on police stations boundaries and police station sector boundaries from the year 2015. The type of analysis used for this research is Optimized Hot Spot Analysis. Results for burglary cases of both areas are divided into two (2) which are daytime and nighttime. The spatial analysis revealed that there are five (5) sectors identified as hot spots for the Northeast Penang Island District which involve Jelutong Police Station boundary and Ayer Itam Police Station boundary, while none of the areas identified as hot spot areas in Kuching District.
\end{abstract}

Keywords: Optimized Hot Spot Analysis, burglary, crime, crime geography

\footnotetext{
${ }^{1}$ Lecturer at Universiti Malaysia Sarawak. Email: mtarmiji@unimas.my
} 
PLANNING MALAYSIA

Journal of the Malaysia Institute of Planners (2021)

\section{INTRODUCTION}

Drug abuse and crime are so relative that there is a correlation. Among the examples of drug abuse problems with an increase in crime are theft, robbery, and burglary. Drug abuse accounts for almost 50 percent of criminal cases occurring in 23 countries and this clearly indicates that there is a link between criminal behavior and drug abuse (Abdullah, 2016). In addition to that, according to the UK's Prime Minister's Strategy Unit (2003), 56 percent of crimes are due to drug abuse of which 85 percent involve shop theft, 70 percent involve burglary, and 54 percent robbery. This suggests that drug abuse contributes to crime activities (UK Strategy Unit Drugs Report, 2003).

Shahrul Nizam (2016) proposed that statistics show that drug abuse makes up almost 50 percent of the criminal cases that occur. Reflecting on that, the percentage shows the connection between criminal acts with drug abuse. However, due to the inaccurate, unreliable, and incomplete manual processes back then, the old system of a criminal record has failed to fulfill and keep up with the need of the existing crime scenario. Hence, it is neither effective nor efficient to be applied until the presence of technology starts to reciprocate (Johnson, 2000). However, the evolution in technology has contributed to vast alterations in the human ability to explore and assess changes, including for criminal activities. Weisburd and McEwen (1997) as cited in Weisburd et al., (2009) also confirmed that criminologist has been paying attention to the relationship between crimes with the location since a long time ago.

As stated by Mohd Reduan (1990), drug addicts will commit crimes, especially those that bring in monetary benefits in a short time such as stealing, robbery, burglary, and so on to get money to buy drugs. Drug abuse causes a person to commit a crime because of the unstable mind and feelings. In addition, the rising cost of drugs will cause drug addicts to commit a crime such as theft, break-in, and violent activities (Hussin, 2005). Typically, crimes were committed by people who are under the influence of drugs as a result of long-term personality changes in the individual that may occur immediately (Wanberg and Milkman, 2008).

\section{LITERATURE REVIEW}

"One of the more influential tools facilitating the exploration of the spatial distribution of crime has been GIS" (Ratcliffe and McCullagh, 1999; Harries, 1999). Crime occurs due to various factors such as the physical arrangement of an area (Greenburg and Rohe, 1984.; Quetelet, 1984), accessibility to the target or victim (Cohen and Felson, 1979; Brantingham and Brantingham, 1981; Quetelet, n.d.). Ferreira et al. (2012), to meet the current need, GIS as a spatialbased tool helps to understand the causes by producing outputs that contain enormous amounts of location-based information. 
Tarmiji Masron, Azizan Marzuki, Nur Faziera Yaakub, Mohd Norashad Nordin, Norita Jubit

Spatial Analysis of Crime Hot-Spot in The Northeast Penang Island District and Kuching District, Malaysia

Chainey (2001) suggested that in the scope of spatial element, crime has an intrinsic geographical quality and it is not randomly distributed, which means that here are possibilities for crime to occur in any place and at different time. Hence, there would be localities with hot spot and cold spot. Grubesic (n.d.), noted that any area which is prone to have higher concentrations of crime compared to other area is generally addressed as hot spot area while any area which has low concentration of crime is known as cold-spot. Chainey (2011) proposed four elements that present and make up a crime namely legal, victim, offender and spatial. Fajemirokun et al. (2006) support that, for crimes to occur, offenders and their targets - the victims and/or property - must exist at the same location for a period of time.

Crime mapping by using Geographic Information System (GIS) is increasingly being used and it has enabled authorities to identify risky areas. Thus, the process of monitoring the focus areas can be enhanced. According to Liu et al. (2005), GIS was used to identify crime and drug abuse areas in Langfang, China. The hot-spot area was determined by using the Point Pattern Test. After that, the results obtained were analyzed with the Average Nearest Neighbor (ANN) method to attain the ANN index and z-values are presented via maps. The results proved that the pattern of drug abuse and crime hot spots was identified in Langfang, China (Liu et al., 2005).

Fuentes and Henandez (2013) applied Kernel Density Estimation (KDE) to study the spatial correlation between property crime with socioeconomic status in Ciudada Juarez Chihuahua, Mexico. The spatial data were the police sector boundaries and land use data. While the non-spatial data were the demographic data and the number of property crime cases in 2008 and 2009. The results showed that clustered spatial pattern of property crime was highly found in areas with low socioeconomic status and areas with crowded business centers.

Robert (2016) conducted a study using spatial statistics namely Kringing interpolation, multiple analysis, and cluster analysis. The unit of analysis is the boundary of residential areas. The attributes were the demographic data and crime data from 2011 until 2013, and the incident locations. The generated outputs found that income and education were the factors that influence crime.

Patel et al. (2014) used thematic maps in analyzing crime in the city of Ahmedabad, India. The non-spatial data used were crime data from July 2011 until December 2011, address, and time. Spatial data consists of police station sector boundaries, police station boundaries, and land-use boundaries. The results showed that most of the burglary cases took place between 12.30 am to $6 \mathrm{am}$. 
PLANNING MALAYSIA

Journal of the Malaysia Institute of Planners (2021)

\section{METHODOLOGY}

The study areas for this research are the Northeast Penang Island District and Kuching District. The Northeast District of Penang which is situated at latitude $5^{\circ} 22^{\prime} 16.28^{\prime}$ ' $N$ and longitude $100^{\circ} 14^{\prime} 14.22^{\prime \prime} ' E$ has an area of $122.79 \mathrm{~km}^{2}$. The district is divided into fifteen mukim namely Mukim 13, Mukim 14, Mukim 15, Mukim 16, Mukim 17, Mukim 18, Bandar Ayer Itam, Bandar Batu Feringghi, Bandar Bukit Bendera, Bandar Glugor, Bandar George Town, Bandar Jelutong, Bandar Tanjong Bungah, Bandar Tanjong Tokong and Bandar Tanjong Pinang. Whereas Kuching District which situated at latitude $1^{\circ} 33^{\prime} 36^{\prime \prime} \mathrm{N}$ and longitude $110^{\circ} 20^{\prime} 42^{\prime \prime} \mathrm{E}$ has an area of $431 \mathrm{~km}^{2}$. Kuching District is divided into two (2) councils namely DBKU (Dewan Bandaraya Kuching Utara) and MBKS (Majlis Bandaraya Kuching Selatan).

Mapping crime hot spot areas using GIS applications involves data from study areas that include location coordinates of incidents based on police stations boundaries and sectors from the year 2015. The spatial analysis applied for this research is Optimized Hot Spot Analysis. Optimized Hot Spot Analysis tool interrogates data to obtain the settings that will yield optimal hot spot results (Getis and Ord, 1992; Ord and Getis, 1995).

Optimized Hot Spot Analysis as a spatial tool on ArcGIS that works by producing a new Output Feature Class with a z-score, p-value, and confidence level bin (Gi_Bin) for each feature. The Gi_Bin field identifies statistically significant hot and cold spots, corrected for multiple testing and spatial dependence using the False Discovery Rate (FDR) correction method. Features in the $+/-3$ bins (features with a Gi_Bin value of either +3 or -3 ) are statistically significant at the 99 percent confidence level; features in the $+/-2$ bins reflect a 95 percent confidence level; features in the $+/-1$ bins reflect a 90 percent confidence level; and the clustering for features with 0 for the Gi_Bin field is not statistically significant.

Table 1: Relations between z-score, $p$-value, and Confidence Level

\begin{tabular}{ccc}
\hline $\begin{array}{c}\text { z-score (Standard } \\
\text { Deviations) }\end{array}$ & p-value (Probability) & Confidence level \\
\hline$<-1.65$ or $>+1.65$ & $<0.10$ & $90 \%$ \\
\hline$<-1.96$ or $>+1.96$ & $<0.05$ & $95 \%$ \\
\hline$<-2.58$ or $>+2.58$ & $<0.01$ & $99 \%$ \\
\hline
\end{tabular}

The results are capable to identify the statistically significant spatial clusters of high values and low values. High values mean hot spots and low values mean cold spots. The outputs generated from the spatial analysis are shown in the attribute table of z-score and p-value to determine the hot spot area of burglary cases. For this research, the scope of criminology is the number of cases of burglary in the Northeast Penang Island District and Kuching District, Malaysia. 
Tarmiji Masron, Azizan Marzuki, Nur Faziera Yaakub, Mohd Norashad Nordin, Norita Jubit

Spatial Analysis of Crime Hot-Spot in The Northeast Penang Island District and Kuching District, Malaysia

\section{RESULTS}

Based on the statistical record, the number of burglary cases recorded in the Northeast Penang Island District in 2015 was 194 cases, of which 66 cases happened during the daytime ( 34 percent), while 128 cases happened at nighttime (66 percent). Table 2 shows the Optimized Hot Spot Value of Burglary Cases in the Northeast Penang Island District in 2015. Based on the z-score and p-value obtained, the identified hot spot areas are Jelutong Police Station and Ayer Itam Police Station. The significant $\mathrm{p}$-value of $\mathrm{p}<0.05$ shows that the localities identified as the hot spot areas for Jelutong Police Station are four (4) sectors that are sector $27,23,28$, and 29 , whereas the locality acknowledged as the hot spot area for Ayer Itam Police Station is sector F.

Jelutong Police Station (Sector 27) recorded the highest z-score among the hot spot areas with a value of 5.430675, followed by Jelutong Police Station (Sector 29) with a value of 3.554131. For Ayer Itam Police Station (Sector F), the value of the $\mathrm{z}$-score obtained is 3.132625. By referring to the value in Table 2 , Jelutong Police Station (Sector 27) noted the highest degree of freedom $(d f)=3$ which reflects the 99 percent confidence level. Figure 1 shows the localities according to the police station's boundaries which are identified as hot spot areas.

Table 2: Optimized Hot Spot Value of Burglary Cases in the Northeast Penang Island District in 2015

\begin{tabular}{ccc}
\hline Police Station (Sector) & Z-Score & P-Value \\
\hline Jelutong Police Station (Sector 27) & 5.430675 & 0.000000 \\
\hline Jelutong Police Station (Sector 23) & 2.94293 & 0.003251 \\
\hline Jelutong Police Station (Sector 28) & 2.679146 & 0.007381 \\
\hline Jelutong Police Station (Sector 29) & 3.554131 & 0.000379 \\
\hline Ayer Itam Police Station (Sector F) & 3.132625 & 0.001733 \\
\hline
\end{tabular}




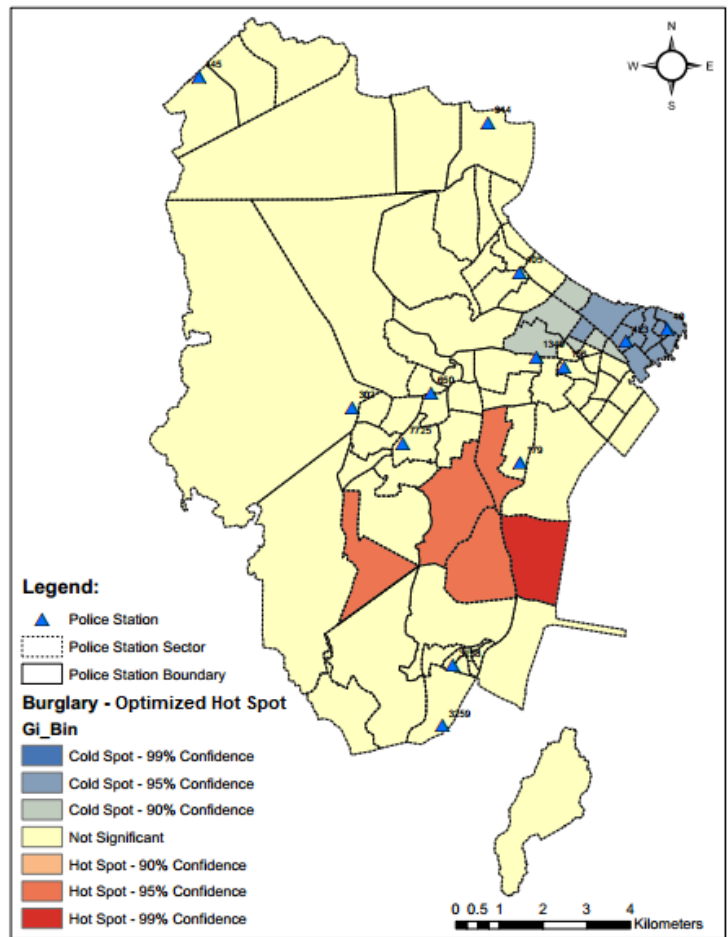

Figure 1: Optimized Hot Spot for Burglary Cases in the Northeast Penang Island District in 2015

Table 3 shows the z-score and p-value based on the Optimized Hot Spot Analysis of burglary cases during daytime and nighttime in the Northeast Penang Island District for the year 2015. Based on a 95 percent confidence level and significant $\mathrm{p}<0.05$, the identified hot spots areas are located within the boundaries of Jelutong Police Station and Tanjung Tokong Police Station. The number of sectors involved for both police station boundaries is six (6) sectors. For the boundary of Jelutong Police Station, the sectors identified as hot spots are 4 sectors, namely sector $27,29,23$, and 28 . Whereas, the other two (2) sectors identified within Tanjung Tokong Police Station are Sector 1 and Sector 2.

The highest z-score for the entire police station sector is Sector 27 with a value of 3.391971 and Sector 29 with a value of 3.310101. These two (2) sectors are located within the boundary of Jelutong Police Station. Whereas Sector 1 and Sector 2 which are located within the boundary of Tanjung Tokong Police Station recorded the lowest z-score. Based on the spatial analysis conducted, the highest $d f$ level recorded for daytime burglary cases is at level 2 and 95 percent confidence level.

Sector 27 and Sector 29 which are located within the border of Jelutong Police Station achieved $d f=2$ which reflects a 95 percent confidence level, while 
Tarmiji Masron, Azizan Marzuki, Nur Faziera Yaakub, Mohd Norashad Nordin, Norita Jubit

Spatial Analysis of Crime Hot-Spot in The Northeast Penang Island District and Kuching District, Malaysia

other sectors only achieve $d f=1$ which means the 90 percent confidence level. Figure 2 and Figure 3 show the police station sector boundaries which are identified as hot spot areas for burglaries during daytime and nighttime in 2015 respectively.

Table 3: Optimized Hot Spot Value of Burglary Case During Daytime and Nighttime in the Northeast Penang Island District, 2015

\begin{tabular}{lllll}
\hline \multirow{2}{*}{ Police Station (Sector) } & \multicolumn{2}{c}{ Daytime } & \multicolumn{2}{c}{ Nighttime } \\
\cline { 2 - 5 } & Z-Score & P-Value & Z-Score & P-Value \\
\hline Jelutong Police Station (Sector 27) & 3.391971 & 0.000694 & 5.059188 & 0.00000 \\
\hline Jelutong Police Station (Sector 29) & 3.310101 & 0.000933 & 3.605416 & 0.000312 \\
\hline Jelutong Police Station (Sector 23) & 2.377696 & 0.017421 & 2.978471 & 0.002897 \\
\hline Jelutong Police Station (Sector 28) & 2.543675 & 0.010969 & 2.478719 & 0.013186 \\
\hline Tanjong Tokong Police Station (Sector 1) & 2.264333 & 0.023554 & - & - \\
\hline Tanjong Tokong Police Station (Sector 2) & 2.264333 & 0.023554 & - & - \\
\hline Ayer Itam Police Station (Sector F) & - & - & 3.350964 & 0.000805 \\
\hline Sg Nibong Police Station (Sector D) & - & - & 2.348375 & 0.018856 \\
\hline Bandar Baru Police Station (Sector 3) & - & - & 2.485252 & 0.012946 \\
\hline
\end{tabular}

Figure 2 shows the boundary of police station recognized as hot spot area based on the z-score and p-value obtained for the analysis of burglary cases during daytime and Figure 3 shows the boundary of police station known as hot spot area based on the z-score and p-value for the analysis of burglary cases during nighttime. An area is classified as a hot spot area if the significant value of $\mathrm{p}$-value is $\mathrm{p}<0.05$ at a 95 percent confidence level.

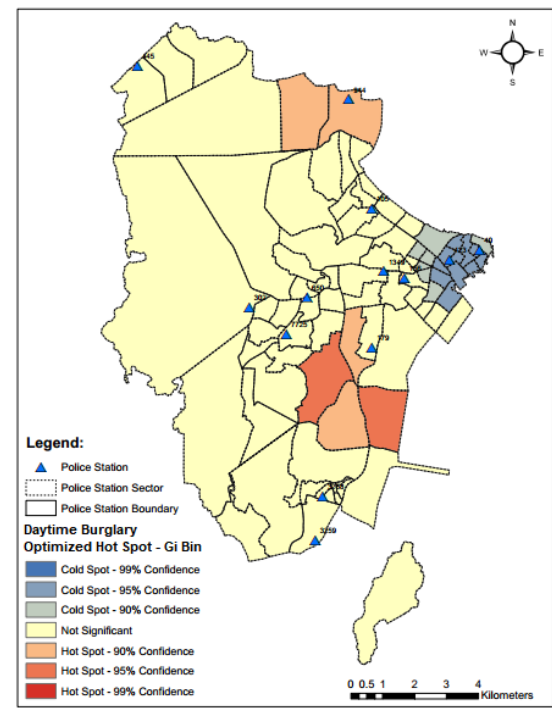

Figure 2: Optimized Hot Spot for Burglary Case During Daytime in the Northeast Penang Island District in 2015 


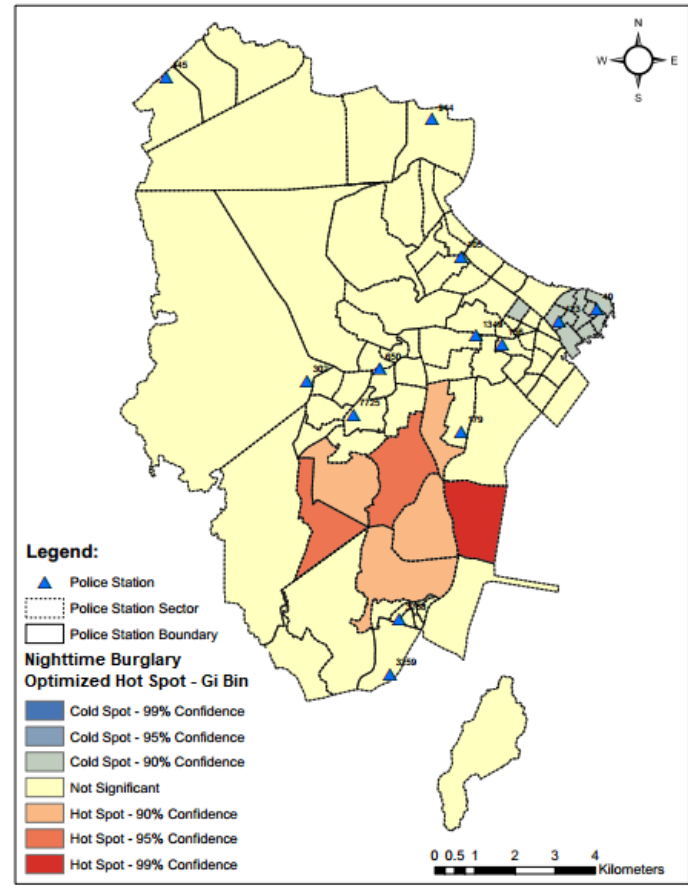

Figure 3: Optimized Hot Spot for Burglary Case During Nighttime in the Northeast Penang Island District in 2015

The number of burglary cases reported in Kuching District in 2015 was 236 cases, of which 146 cases (62 percent) occurred during daytime and 90 cases ( 38 percent) occurred during nighttime. Table 4 and Figure 4 show the localities according to police station's boundaries which are identified as hot spot areas.

Overall, results show that most areas are not significant because the $p$ value obtained indicates $p>0.10$. However, spatial analysis on the other hand revealed that there are sectors identified as cold spot areas for burglary cases in Kuching District for 2015. Table 4 shows the police station boundaries identified as cold spot areas for burglary cases. Based on the z-score and p-value obtained, there are 11 police station sectors known as cold spot areas involving the boundaries of Tabuan Jaya Police Station, Sekama Police Station, and Sentral Police Station. For the boundary of Tabuan Jaya Police Station, the entire sector which covers from Sector 1 to Sector 7 are all classified as cold spot areas. For Sentral Police Station, the cold spot area involves three (3) sectors namely Sector 4, Sector 5, and Sector 7. Whereas, for Sekama Police Station, there is only one (1) sector which is classified as a cold spot area that is Sector 1.

Based on the z-score and p-value obtained, there are seven (7) sectors with cold spot areas at 95 percent confidence level and the four (4) sectors with 
Tarmiji Masron, Azizan Marzuki, Nur Faziera Yaakub, Mohd Norashad Nordin, Norita Jubit

Spatial Analysis of Crime Hot-Spot in The Northeast Penang Island District and Kuching District, Malaysia

cold spot area at 90 percent confidence level. Sectors showing the cold spot area at 95 percent confidence level are Sentral Police Station (Sector 4, Sector 5 and Sector 7); Tabuan Jaya Police Station (Sector 5, Sector 6, and Sector 7); and Sekama Police Station (Sector 1). For the 90 percent confidence level, the cold spot areas identified are namely Sector 1, Sector 2, Sector 3, and Sector 4 in the boundary of Tabuan Jaya Police Station.

Based on Table 4, the cold spot area that recorded the lowest $\mathrm{z}$-score of -3.19302 and $p$-value of $0.001408(p<0.05)$ is Sector 1 that is located within the boundary of Sekama Police Station. Whereas, the cold spot area that records the highest $\mathrm{z}$-score of -2.600071 and $\mathrm{p}$-value of $0.00932(\mathrm{p}>0.10)$ is Sector 1 that is situated within the boundary of Tabuan Jaya Police Station.

Table 4: Optimized Hot Spot Value of Burglary Cases in Kuching District, 2015

Police Station (Sector)

Z-Score

P-Value

\begin{tabular}{ccc}
\hline Tabuan Jaya Police Station (Sector 1) & -2.600071 & 0.00932 \\
\hline Tabuan Jaya Police Station (Sector 2) & -2.600071 & 0.00932 \\
\hline Tabuan Jaya Police Station (Sector 3) & -2.631259 & 0.008507 \\
\hline Tabuan Jaya Police Station (Sector 4) & -2.366861 & 0.01794 \\
\hline Tabuan Jaya Police Station (Sector 5) & -3.19302 & 0.001408 \\
\hline Tabuan Jaya Police Station (Sector 6) & -3.328743 & 0.000872 \\
\hline Tabuan Jaya Police Station (Sector 7) & -3.514273 & 0.000441 \\
\hline Sentral Police Station (Sector 4) & -3.542051 & 0.000397 \\
\hline Sentral Police Station (Sector 7) & -2.75646 & 0.005843 \\
\hline Sekama Police Station (Sector 1) & -2.843574 & 0.004461 \\
\hline Sentral Police Station (Sector 5) & -3.19302 & 0.001408 \\
\hline
\end{tabular}


PLANNING MALAYSIA

Journal of the Malaysia Institute of Planners (2021)

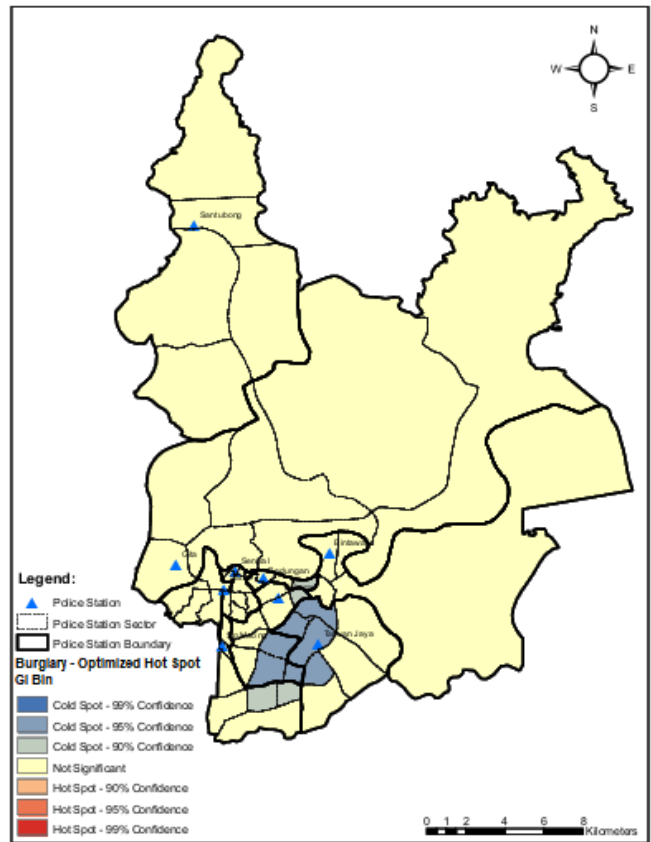

Figure 4: Optimized Hot Spot for Burglary Cases in Kuching District in 2015

Table 5 shows the results of Optimized Hot Spot analysis for burglary cases in Kuching District in 2015 during daytime and nighttime. Santubong Police Station (Sector 5) was identified as a hot spot area during daytime, while the hot spot area during nighttime is Gita Police Station (Sector 2).

Based on a 90 percent confidence level and significant value $\mathrm{p}<0.10$, the hot spot area for burglary during daytime is Santubong Police Station (Sector 5) with a z-score of 2.44755 and a p-value of 0.01438 while Gita Police Station (Sector 2) with a z-score of 3.19106 and a p-value of 0.00142 was identified as the hot spot area during nighttime.

Table 5: Optimized Hot Spot Value of Burglary Case in Kuching District, 2015

\begin{tabular}{llccc}
\hline \multirow{2}{*}{ Police Station (Sector) } & \multicolumn{2}{c}{ Daytime } & \multicolumn{2}{c}{ Nighttime } \\
\cline { 2 - 5 } & Z-Score & P-Value & Z-Score & P-Value \\
\hline Santubong Police Station (Sector 5) & 2.44755 & 0.01438 & - & - \\
\hline Gita Police Station (Sector 2) & - & - & 3.19106 & 0.00142 \\
\hline
\end{tabular}


Tarmiji Masron, Azizan Marzuki, Nur Faziera Yaakub, Mohd Norashad Nordin, Norita Jubit

Spatial Analysis of Crime Hot-Spot in The Northeast Penang Island District and Kuching District, Malaysia

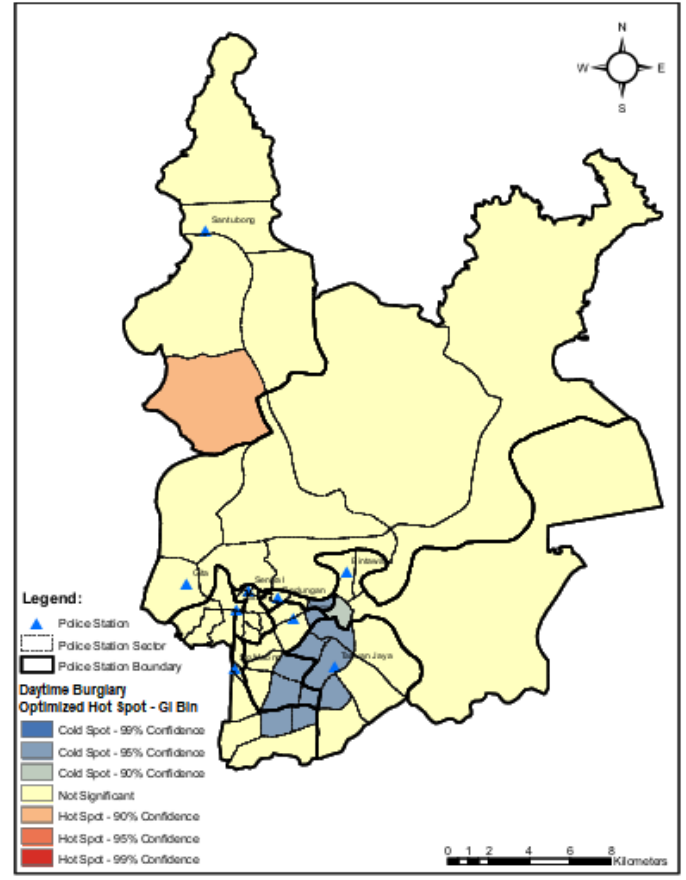

Figure 5: Optimized Hot Spot for Burglary Case During Daytime in Kuching District in 2015

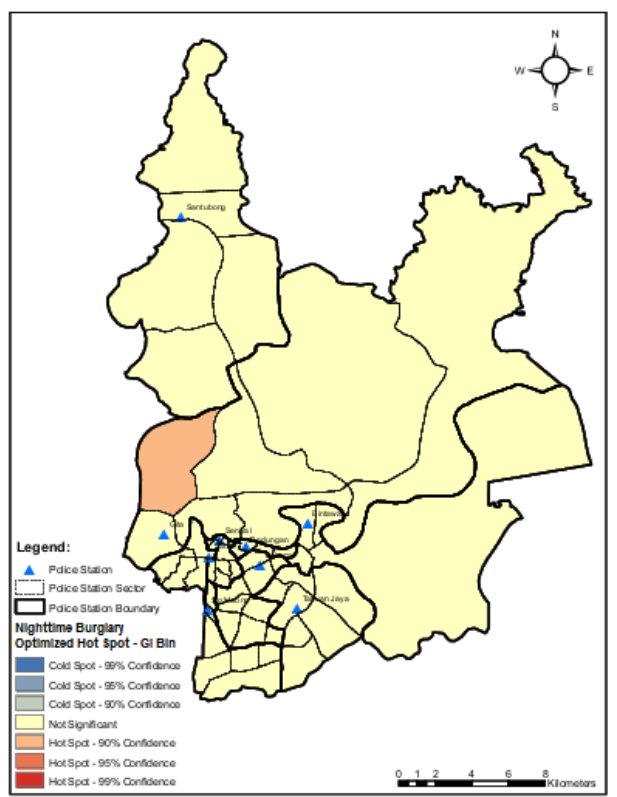

Figure 6: Optimized Hot Spot for Burglary Case During Nighttime in Kuching District in 2015 
PLANNING MALAYSIA

Journal of the Malaysia Institute of Planners (2021)

\section{DISCUSSION}

Crime may present due to the changes that occur in the attitudes and behaviors of individuals especially those who live in an urban environment and practice a modern lifestyle. The behavior of criminals may also ignite potential actions of other people towards criminals or the opportunity to be involved in a particular space and time (Faizah, 2015). The rate of crime cases increases in tandem with the population growth rate and the rise in the rate of economic expansion, hence making the security aspect as the basis of current urban environment planning as what is happening in Penang, Malaysia (Sophie, 2000).

A high number of criminal activities have been reported in urban areas and the rapid development shows that municipalities are among the factors that greatly influence the increase in the number of criminal cases. For that matter, it has also led the world towards increasingly complex criminal problems. Possibilities for criminal activities such as robbery and burglary will be higher if the area is knowingly high with drug abuse cases (Mohd Norashad and Tarmiji, 2016).

Crime occurs due to the motivation of criminal offenders, the appropriate targets, and the absence of oversight that can prevent the occurrence of crime in the environment. Criminal targets may involve people or objects and the lack of supervision will risk the occurrence of crime (Adewumi et al., 2017). The low count of criminal incidents is due to supervision from authorities such as police, RELA as well as neighborhoods' communities in residential or village areas. Any type of crime, including burglary, have a variety of factors such as the lighting level at the surrounding, door and key types, emergency alarm sounds, and any possibility to be observed either by neighbors or by people in the neighborhood area (Zuriatunfadzliah et al., 2019).

The Daily Activity Theory explains that criminals will take into account the environmental and daily activities of the target area such as the group of people living in the area, their workplace distance, the public who are passing through the area as well as the social activities. In addition, criminal events usually occur during weekdays or when the owners are away from their abodes. This is to ensure that no eyewitness will see the activities (Siti Rasidah dan Adrian, 2008).

\section{CONCLUSION}

The hot spot areas for crimes are continuously changing due to the crime prevention initiatives or programs that have been applied to an area such as supervision and patrolling by authorities, RELA, and the cooperation from neighbors. The potential of changing of crimes is often associated with mechanically criminal control programs such as the use of key systems, emergency sounds, and closed-circuit cameras. However, the changing and 
Tarmiji Masron, Azizan Marzuki, Nur Faziera Yaakub, Mohd Norashad Nordin, Norita Jubit

Spatial Analysis of Crime Hot-Spot in The Northeast Penang Island District and Kuching District, Malaysia

shifting of criminal locations from one target area to another occur without reducing the crime rate as a whole.

\section{ACKNOWLEDGEMENT}

This paper was funded under Kementerian Pengajian Tinggi Malaysia, Fundamental Research Grant Scheme, FRGS/1/2020/SS0/UNIMAS/01/1 and UNIMAS Postdoctoral Research Program. The authors wish to express appreciation to Royal Malaysian Police Headquarters, Bukit Aman for giving support and cooperation.

\section{REFERENCES}

Abdullah, S. N. (2016). Kosmo. Perangilah Dadah Habis- habisan, p. 11.

Adewumi, I. B., Abel, O. A. \& Olanrewaju, T. D. (2017). Seasonality of violent and property crime in Nigeria: Some Preliminary Findings. International Journal of Criminology and Sociological Theory, Vol. 10, No. 2, 1-23.

Brantingham, P. and Brantingham, P. (1981). Environmental Criminology. Beverly Hills; Sage.

Chainey, S. (2001). GIS and Crime Mapping. UCL Jill Dando Institute of Crime Science. 145.

Cohen, L. and Felson, M. (1979). Social Change and Crime Rate Trends: A Routine Activity Approach. American Sociological Review. 44:588-608.

Fajemirokun, F., Adewale, O., Idowu, T., Oyewusi, A., \& Maiyegun, B. (2006). A GIS Approach to Crime Mapping and Management in Nigeria: A Case Study of Victoria Island Lagos. 1-17.

Faizah Md Latif. (2015). ke arah pengurangan indeks jenayah jalanan di Pusat Bandar Kuala Lumpur. Malaysian Journal of Society and Space 11 issue 4, 97 - 107.

Ferreira, J., João, P and Martins, J. (2012). "GIS for Crime Analysis - Geography for Predictive Models" The Electronic Journal Information Systems Evaluation. 15(1) 2012. $36-49$.

Fuentes, C. M., \& Hernandez, V. (2013). Assessing spatial pattern of crime in Ciudad Juárez, Chihuahua, Mexico (2009): The macrolevel, mesolevel and microlevel approaches. International Journal of Criminology and Sociological Theory, 6(4), 242-259.

Getis, A. and J.K. Ord. (1992). The Analysis of Spatial Association by Use of Distance Statistics in Geographical Analysis 24(3).

Greenburg, S. and Rohe, W. (1984). Neighborhood Design and Crime. Journal of the American Planning Association. 50: 48-61.

Grubesic, T. H. (n.d.). Detecting Hot Spots Using Cluster Analysis and GIS.

Harries, K. (1999). Mapping Crime: Principle and Practice. Washington DC: National Institute of Justice (NCJ 178919).

Hussin, H. (2005). Penyalahgunaan Dadah. Retrieved from dspace.unimap.edu.my: http://dspace.unimap.edu.my/dspace/bitstream/123456789/1701/1/Penyalahgunaan \%20Dadah.pdf

Johnson, C. P. (2000). Crime Mapping and Analysis Using GIS. Conference on Geomatics in Electronic Governance. 1-5. 
Liu, L., Wang, X., Eck, J., \& Liang, J. (2005). Simulating crime events and crime patterns in a RA/CA model. In: F. Wang (Ed.), Geographic information systems and crime analysis. 197-213. Reading, PA: Idea Publishing.

Mohd Norashad, N. \& Tarmiji, M. (2016). Analisis ruangan hot spot penyalahgunaan dadah di Malaysia: Kajian kes Daerah Timur Laut, Pulau Pinang. GEOGRAFIA Malaysian Journal of Society and Space. 12(5). 74-82.

Mohd Reduan, R. (1990). Krisis Dadah. Kuala Lumpur: AMK Interaksi Sdn. Bhd.

Ord, J.K. \& A. Getis. (1995). Local Spatial Autocorrelation Statistics: Distributional Issues and an Application in Geographical Analysis 27(4).

Patel, K., Thakkar, P., Patel, L., \& Parekh, C. (2014). GIS based decision support system for crime mapping, analysis and identify hotspot in Ahmedabad City. International Journal of Modern Engineering Research, 4(1), 32-35.

Quetelet, A. (1984). Research on the propensity for crime at different ages, translated and with an introduction by S.F. Sylvester. Cincinnati: Anderson Publishing.

Ratcliffe, J. H. \& McCullagh, M. J. (1999). Hotbeds of Crime and the Search for Spatial Accuracy. Journal of Geographical Systems. 1: 385-398.

Robert, R. A. (2016). Exploring residential crime prediction with GIS-demographic profiles vs top offender location: A Rochester, Minnesota USA case study. Resource Analysis, 19, 2-14.

Shahrul Nizam, A. (2016). Kosmo. Perangilah Dadah Habis- habisan. 11.

Siti Rasidah, M. S. \& Adrian, A. (2008). Jenayah Dan Persekitaran: Hubungan Dan Perkaitannya. Seminar Penyelidikan Siswazah Alam Bina. 1-16. Perak: www.academia.edu.

Sophie, B. (2000). The Social Control of Cities? A Comparative Perspective. United Kingdom: Blackwell Publishing.

Tong, T. I. (1975). Opium in the Straits Settlements 1867-1909.

UK Strategy Unit Drugs Report. (2003, Februari). Analysis of the harms caused by crack and heroin. Retrieved from evolvecms.webfreelancersuk.co.uk: http://evolvecms.webfreelancersuk.co.uk/sites/default/files/Strategy\%20Unit\%20dr ugs\%20report.pdf

Wanberg, K., \& Milkman, H. (2008). Criminal Conduct and Substance Abuse Treatment The Provider's Guide. United State of America: SAGE Publication.

Weisburd, D., Bernasco, W. \& Bruinsma, G. J. N. (2009). Putting Crime in its Place. Units of Analysis in Geographic Criminology. 3-245. Dordrecht Heidelberg London, NY: Springer.

Weisburd, D., \& McEwen, T. (1997). Introduction: Crime mapping and crime prevention. In: D. Weisburd \& T. McEwen (Eds.), Crime mapping and crime prevention. 1-23. Monsey, NY: Criminal Justice Press.

Zuriatunfadzliah, S. \& Noraziah Alit, S. I. (2019). Topophobia Wanita dan Hubungannya dengan Kejadian Jenayah di Pantai Dalam, Kuala Lumpur, Malaysia. Didapatkan dari www.myjurnal.my:http://www.myjurnal.my/filebank/published_article/30136/7.PD F

Received: $5^{\text {th }}$ November 2021. Accepted: $5^{\text {th }}$ December 2021 